\title{
Algoritma K-Medoids Untuk Menentukan Calon Mahasiswa Yang Layak Mendapatkan Beasiswa Bidikmisi di Universitas Budi Darma
}

\author{
Efori Buulolo*, Rian Syahputra, Alwin Fau \\ Fakultas Ilmu Komputer dan Teknologi Informasi, Universitas Budi Darma, Medan, Indonesia \\ Email: 1,* buuloloefori21@gmail.com, ${ }^{2}$ ryansyah93@gmail.com, ${ }^{3}$ alwinfau@gmail.com \\ Email Penulis Korespondensi: buuloloefori21@gmail.com
}

\begin{abstract}
Abstrak-Beasiswa bidikmisi merupakan program pemerintah untuk membantu calon mahasiswa baru yang mampu secara akademik dan tidak mampu secara ekonomi. Bentuk beasiswa bidikmisi yaitu bantuan biaya pendidikan dan bantuan biaya hidup. Mulai tahun 2018 Universitas Budi Darma mulai menerima mahasiswa baru melalui jalur beasiswa bidikmisi, penerimaan mahasiswa baru melalui jalur bidikmisi harus memenuhi persyaratan yang telah ditetapkan oleh pemerintah. Penentuan layak atau tidak seorang calon mahasiswa baru penerima bidikmisi berdasarkan nilai raport, prestasi disekolah, hasil ujian seleksi dan wawancara. Selama ini pihak penyelenggara dan pengelola bidikmisi di Universitas Budi Darma kesulitan menentukan calon mahasiswa yang benar-benar layak menerima beasiswa bidikmisi selain karena kuota yang sangat terbatas dan jumlah calon mahasiswa penerima beasiswa bidikmisi yang banyak juga karena nilai setiap kriteria calon mahasiswa penerima bidikmisi yang hampir sama atau mirip antara satu dengan lainnya. Untuk memudahkan dalam menentukan calon mahasiswa penerima beasiswa bidikmisi tersebut digunakan algoritma K-Medoids. Algoritma K-Medoids merupakan salah satu algoritma dalam data mining untuk mengelompokan data berdasarkan nilai kriteria terdekat.
\end{abstract}

Kata Kunci: Mahasiswa, Beasiswa, Bidikmisi, Algoritma, K-Medoids

\begin{abstract}
Bidikmisi scholarship is a government program to help prospective new students who are academically capable and economically incapable. The Bidikmisi scholarship is a form of tuition assistance and living expenses. Starting in 2018 Budi Darma University began accepting new students through the bidikmisi scholarship path, admission of new students through the bidikmisi path must meet the requirements set by the government. Determination of whether or not a prospective new student is a recipient of bidikmisi based on report cards, school performance, results of selection tests and interviews. During this time the organizers and managers of bidikmisi at Budi Darma University have had difficulty determining prospective students who are truly eligible to receive bidikmisi scholarships in addition to the very limited quota and the large number of prospective students receiving bidikmisi scholarships as well as the value of each criteria for prospective students receiving bidikmisi which is almost the same or similar to one another. To make it easier to determine prospective students receiving the Bidikmisi scholarship, the K-Medoids algorithm is used. K-Medoids algorithm is one of the algorithms in data mining to group data based on the closest criteria value.
\end{abstract}

Keywords: Students, Scholarships, Bidikmisi, Algorithms, K-Medoids

\section{PENDAHULUAN}

Program beasiswa bidikmisi merupakan program pemerintah untuk membantu calon mahasiswa yang mampu secara akademik dan tidak mampu secara ekonomi[1]. Program beasiswa bidikmisi mulai diselenggarakan pada tahun 2010 dengan tujuan untuk meningkatkan akses dan kesempatan belajar bagi keluarga atau masyarakat yang kurang mampu. Penyelengara dan pengelola beasiswa bidikmisi bukan hanya Perguruan Tinggi Negeri tetapi juga Perguruan Tinggi Swasta yang memenuhi persyarakat yang telah ditentukan.

Bentuk beasiswa bidikmisi yang diberikan pemerintah kepada mahasiswa penerima adalah bantuan biaya pendidikan yang ditransfer langsung kerekening Perguruan Tinggi dan biaya hidup yang ditransfer langsung kerekening mahasiswa penerima sehingga mahasiswa dapat bebas dari uang pangkal, SPP dan biaya lainnya. Calon mahasiswa yang layak menerima bidikmisi adalah mahasiswa yang memenuhi persayaratan atau kriteria yang telah ditetapkan pemerintah seperti mempunyai prestasi dan kurang mampu secara ekonomi serta kriteria lainnya. Mulai pada tahun 2018 salah satu program studi di Universitas Budi Darma(sebelumnya STMIK Budi Darma) sudah terakreditas B(Baik) yaitu Teknik Informatika sehingga Universitas Budi Darma memenuhi persyaratan untuk menyelenggarakan dan mengelola beasiswa bidikmisi. Mulai TA. 2018/2019 Universitas Budi Darma menerima calon mahasiswa baru melalui jalur beasiswa bidikmisi. Penerimaan calon mahasiswa melalui jalur beasiswa bidikmisi di Universitas Budi Darma berdasarkan kriteria dan ketentuan yang ditetapkan oleh pemerintah yang tertulis pada Buku Panduan Bidikmisi.

Calon mahasiswa penerima beasiswa bidikmisi di Universitas Budi Darma selain harus memenuhi kriteria dan ketentuan yang telah ditetapkan juga harus mengikuti ujian seleksi tertulis dan wawancara yang dilaksanakan oleh Universitas Budi Darma melalui seleksi mandiri. Penentuan layak atau tidaknya seorang calon mahasiswa penerima beasiswa bidikmisi yaitu berdasarkan nilai raport, prestasi disekolah, tingkat ekonomi keluarga, hasil ujian tertulis dan wawancara. Berhubung jumlah kuota penerima beasiswa bidikmisi setiap tahunnya sangat terbatas maka tidak semua calon mahasiswa penerima bidikmisik yang mengikuti ujian seleksi dan wawancara diterima. Selama ini pihak penyelenggara dan pengelola bidikmisi di Universitas Budi Darma kesulitan menentukan calon mahasiswa yang benar-benar layak menerima beasiswa bidikmisi selain karena kuota yang sangat terbatas dan jumlah calon mahasiswa penerima beasiswa bidikmisi yang banyak juga karena nilai setiap kriteria calon mahasiswa penerima bidikmisi yang hampir sama atau mirip antara satu dengan lainnya. Oleh karena 
JURNAL MEDIA INFORMATIKA BUDIDARMA

Volume 4, Nomor 3, Juli 2020, Page 797-805

ISSN 2614-5278 (media cetak), ISSN 2548-8368 (media online)

Available Online at https://ejurnal.stmik-budidarma.ac.id/index.php/mib

DOI 10.30865/mib.v4i3.2240

itu dibutuhkan suatu algoritma yang dapat mengelompokan calon mahasiswa penerima bidikmisi yang benar-benar layak menerima beasiswa bidikmisi.

Data mining adalah teknik pencarian informasi / pengetahuan / penggalian informasi / pengetahuan dari data yang berukuran besar[2]. Salah satu fungsi dan tujuan data mining adalah fungsi clustering / pengelompokkan artinya data yang memiliki kemiripan dikelompokan ke dalam satu cluster[3][4]. Pada tahun 2017 oleh Dyang Falila Pramesti, dkk melakukan penelitian dengan topik pengelompokan potensi kebakaran hutan / lahan dengan algoritma K-Medoids clustering. Hasil penelitian menyimpulkan bahwa cluster satu menghasilkan nilai rata-rata brightness temperature lebih dari $330^{\circ} \mathrm{K}$ dan nilai rata-rata confidence lebih dari $80 \%$ sehingga memiliki potensi tinggi kebakaran hutan / lahan. Cluster dua menghasilkan nilai rata-rata brightness temperature kurang dari $330^{\circ} \mathrm{K}$ dan nilai rata-rata confidence dibawah $80 \%$ sehingga potensi sedang kebakaran hutan / lahan[5]. Begitu juga penelitian yang dilakukan oleh Wiwit Agus Triyanto pada tahun 2015 dengan topik algoritma K-Medoids untuk menentukan strategi pemasaran produk. Hasi penelitian adalah strategi pemasaran produk dapat dilakukan melalui promosi berdasarkan jumlah barang yang paling banyak dibeli[6].

Berdasarkan uraian diatas, algoritma K-Medoids sangat cocok untuk pengelompokan data-data berdasarkan kriteria [7]. Algoritma K-Medoids adalah salah satu teknik dalam data mining untuk mengelompokkan (clustering) data kedalam beberapa kelompok berdasarkan jarak, kriteria, kondisi dan karakteristik [8][9].

\section{METODE PENELITIAN}

\subsection{Kerangka Penelitian}

Berikut adalah kerangka penelitian yang dilakukan oleh penulis:

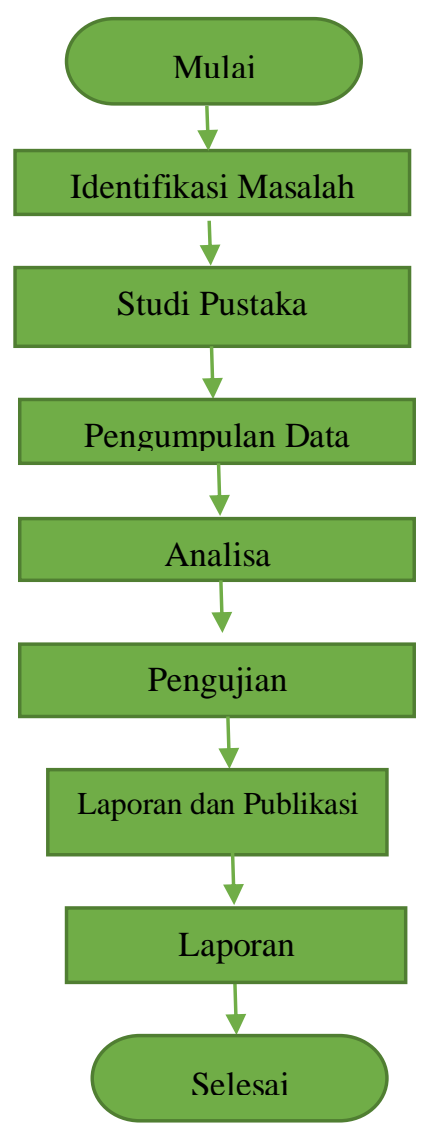

Gambar 1. Kerangka Penelitian

1. Identifikasi Masalah

Penulis mengidentifikasi masalah yang akan menjadi pokok penelitian. Penulis mengidentifikasi masalah yaitu adanya kesulitan yang dialami oleh pihak penyelenggara dan pengelola bidikmisi di Universitas Budi Darma berdasarkan rumusan masalah yang telah diuraikan dilatar belakang masalah.

2. Studi Pustaka

Setelah penulis mengidentifikasi masalah, penulis mempelajari teori-teori yang berkaitan dengan pokok pembahasan. Teori tersebut diperoleh dari buku, jurnal, prosiding, artikel, dan internet.

3. Pengumpulan Data

Penulis melakukan observasi langsung dengan melakukan wawancara kepada pihak penyelenggara dan pengelola bidikmisi Universitas Budi Darma sekaligus pengambilan sampel data untuk penelitian ini. 
4. Analisa

Data yang telah dikumpulkan dianalisa untuk mengetahui yang menjadi pokok masalah dan solusi dari penelitian sesuai dengan topik pembahasan. Pokok masalah dalam penelitian ini adalah adanya kesulitan dari pihak penyelenggara dan pengelolah beasiswa bidikmisi Universitas Budi Darma dalam menentukan calon mahasiswa penerima beasiswa bidikmisi yang benar-benar layak menerima karena kuota yang sangat terbatas sedangkan jumlah calon penerima banyak dan kriteria serta nilai calon penerima yang hampir sama.

5. Penerapan

Untuk membantu pihak penyelanggara dan pengelola beasiswa bidikmisi di Universitas Budi Darma dalam mengelompokan calon penerima beasiswa bidikmisi yang benar-benar layak menerima, maka digunakan teknik data mining algoritma K-Medoids.

6. Pengujian

Perhitungan manual dengan data calon penerima beasiswa bidikmisi menggunakan algoritma K-Medoids menghasilkan pengelompokan data mahasiswa yang benar-benar layak menerima dan yang tidak layak. Dengan menggunakan data yang sama maka data dikelompokan menggunakan aplikasi Rapidminer, tujuannya adalah untuk membanding perhitungan manual dan perhitungan berbasis komputer, jika hasilnya sama atau hampir menyerupai maka proses serta data yang digunakan sudah benar.

7. Laporan

Tahap yang dilakukan penulis dalam penelitian ini adalah menulis laporan penelitian dan melakukan publikasi dalam bentuk karya ilmiah.

\subsection{Sampel Data}

Data yang digunakan sebagai sampel data dalam analisa data mahasiswa yang layak mendapat beasiswa bidikmisi di Universitas Budi Darma adalah data calon penerima beasiswa bidikmisi yang telah mendaftar dan mengikuti proses penerimaan calon mahasiswa dengan jalur beasiswa bidikmisi.

Tabel 1. Data calon penerima beasiswa bidikmisi

\begin{tabular}{|c|c|c|c|c|c|c|}
\hline No. & $\begin{array}{l}\text { Nama Calon } \\
\text { Mahasiswa }\end{array}$ & $\begin{array}{l}\text { Nilai Ujian } \\
\text { Seleksi }\end{array}$ & Prestasi di Sekolah & $\begin{array}{l}\text { Ekonomi } \\
\text { Keluarga }\end{array}$ & $\begin{array}{c}\text { Status } \\
\text { Kepemilikan } \\
\text { Rumah } \\
\end{array}$ & $\begin{array}{l}\text { Dinding- } \\
\text { Lantai } \\
\text { Rumah } \\
\end{array}$ \\
\hline 1 & $\begin{array}{l}\text { Cici Alfiani } \\
\text { Pradika Dita }\end{array}$ & 20 & $\begin{array}{l}\text { Rata-rata Ranking } 7 \\
\text { Kelas }\end{array}$ & $\begin{array}{l}\text { Cukup } \\
\text { Mampu }\end{array}$ & $\begin{array}{l}\text { Milik } \\
\text { Sendiri }\end{array}$ & $\begin{array}{c}\text { Batu } \\
\text { Keramik }\end{array}$ \\
\hline 2 & Tantri Cepti Buana & 20 & $\begin{array}{l}\text { Rata-rata Ranking } \\
15 \text { Kelas }\end{array}$ & $\begin{array}{l}\text { Cukup } \\
\text { Mampu }\end{array}$ & $\begin{array}{l}\text { Milik } \\
\text { Sendiri }\end{array}$ & $\begin{array}{l}\text { Semen } \\
\text { Keramik }\end{array}$ \\
\hline 3 & Tiara Syahri Hsb & 38 & $\begin{array}{l}\text { Rati-rata Ranking } 3 \\
\text { Kelas }\end{array}$ & $\begin{array}{l}\text { Kurang } \\
\text { Mampu }\end{array}$ & Sewa & Papan Semen \\
\hline 4 & Rasiddin Rambe & 24 & $\begin{array}{l}\text { Rara-rata Ranking } 8 \\
\text { Kelas }\end{array}$ & $\begin{array}{l}\text { Kurang } \\
\text { Mampu }\end{array}$ & $\begin{array}{l}\text { Milik } \\
\text { Sendiri }\end{array}$ & Papan Semen \\
\hline 5 & Miranda Putri & 25 & $\begin{array}{l}\text { Rata-Rata Ranking } \\
12 \text { Kelas }\end{array}$ & $\begin{array}{l}\text { Cukup } \\
\text { Mampu }\end{array}$ & $\begin{array}{l}\text { Milik } \\
\text { Sendiri }\end{array}$ & $\begin{array}{l}\text { Semen } \\
\text { Keramik }\end{array}$ \\
\hline 6 & Khairunnisah & 40 & $\begin{array}{l}\text { Rata-rata Ranking } 2 \\
\text { Kelas }\end{array}$ & $\begin{array}{l}\text { Tidak } \\
\text { Mampu }\end{array}$ & $\begin{array}{l}\text { Milik } \\
\text { Sendiri }\end{array}$ & Papan Semen \\
\hline 7 & Ari Pradana & 43 & $\begin{array}{l}\text { Rata-rata rangking } \\
1 \text { Kelas }\end{array}$ & $\begin{array}{l}\text { Kurang } \\
\text { Mampu }\end{array}$ & $\begin{array}{l}\text { Milik } \\
\text { Sendiri }\end{array}$ & $\begin{array}{l}\text { Semen } \\
\text { Semen }\end{array}$ \\
\hline 8 & $\begin{array}{l}\text { Diana Prata Yanti } \\
\text { Simangungsong }\end{array}$ & 47 & $\begin{array}{l}\text { Rata-rata Ranking } 5 \\
\text { Kelas }\end{array}$ & $\begin{array}{l}\text { Cukup } \\
\text { Mampu }\end{array}$ & $\begin{array}{l}\text { Milik } \\
\text { Sendiri }\end{array}$ & $\begin{array}{l}\text { Semen } \\
\text { Keramik }\end{array}$ \\
\hline 9 & Tri Rizky Ananda & 41 & $\begin{array}{l}\text { Rata-rata Ranking } 5 \\
\text { Kelas }\end{array}$ & $\begin{array}{l}\text { Tidak } \\
\text { Mampu }\end{array}$ & Sewa & $\begin{array}{l}\text { Semen } \\
\text { Semen }\end{array}$ \\
\hline 10 & $\begin{array}{l}\text { Wiyuda Pratama } \\
\text { Maharaikan }\end{array}$ & 37 & $\begin{array}{l}\text { Rata-rata Ranking } 5 \\
\text { Kelas }\end{array}$ & $\begin{array}{l}\text { Kurang } \\
\text { Mampu }\end{array}$ & $\begin{array}{l}\text { Milik } \\
\text { Sendiri }\end{array}$ & $\begin{array}{l}\text { Semen } \\
\text { Semen }\end{array}$ \\
\hline 11 & $\begin{array}{l}\text { Anggy Editya } \\
\text { Pratama }\end{array}$ & 43 & $\begin{array}{l}\text { Rata-rata Rangking } \\
9 \text { Kelas }\end{array}$ & $\begin{array}{l}\text { Cukup } \\
\text { Mampu }\end{array}$ & $\begin{array}{l}\text { Milik } \\
\text { Sendiri }\end{array}$ & $\begin{array}{c}\text { Batu } \\
\text { Keramik }\end{array}$ \\
\hline
\end{tabular}

Algoritma K-Medoids dengan persamaan Euclidean distance tidak dapat memproses data yang berupa huruf, maka kriteria dari data calon mahasiswa penerima bidikmisi dirubah kebentuk angka. Kriteria Nilai Ujian Seleksi diranking berdasarkan perolehan nilainya yaitu 47(1), 43(2), 43(2), 41(3), 40(4), 38(5), 37(6), 25(7), 24(8), 20(9), dan 20(9). Kriteria Prestasi Sekolah yaitu rata-rata ranking 1 kelas(1), rata-rata ranking 2 kelas(2), rata-rata ranking 3 kelas(3), rata-rata ranking 5 kelas(5), rata-rata ranking 1 kelas(1), rata-rata ranking 7 kelas(7), rata-rata ranking 8 kelas(8), rata-rata ranking 9 kelas(9), rata-rata ranking 12 kelas(12), dan rata-rata ranking 15 kelas(15). Kriteria Ekonomi Keluarga yaitu tidak mampu(1), kurang mampu(2), dan cukup mampu(3). Kriteria Status Kepemilikan Rumah yaitu sewa(1), dan milik sendiri(2). Kriteria Dinding Lantai Rumah yaitu papan-semen(1), semen-semen(2), semen $\operatorname{keramik}(3)$, dan batu keramik(4). 
ISSN 2614-5278 (media cetak), ISSN 2548-8368 (media online)

Available Online at https://ejurnal.stmik-budidarma.ac.id/index.php/mib

DOI 10.30865/mib.v4i3.2240

Tabel 2. Data calon penerima beasiswa bidikmisi dalam bentuk angka

\begin{tabular}{|c|c|c|c|c|c|c|}
\hline No. & Nama Mahasiswa & $\begin{array}{c}\text { Nilai Ujian } \\
\text { Seleksi }\end{array}$ & $\begin{array}{l}\text { Prestasi di } \\
\text { Sekolah }\end{array}$ & $\begin{array}{l}\text { Ekonomi } \\
\text { Keluarga }\end{array}$ & $\begin{array}{c}\text { Status } \\
\text { Kepemilikan } \\
\text { Rumah }\end{array}$ & $\begin{array}{c}\text { Dinding } \\
\text { Lantai } \\
\text { Rumah }\end{array}$ \\
\hline 1 & Cici Alfiani Pradika Dita & 9 & 7 & 3 & 2 & 4 \\
\hline 2 & Tantri Cepti Buana & 9 & 15 & 3 & 2 & 3 \\
\hline 3 & Tiara Syahri Hsb & 5 & 3 & 2 & 1 & 1 \\
\hline 4 & Rasiddin Rambe & 8 & 8 & 2 & 2 & 1 \\
\hline 5 & Miranda Putri & 7 & 12 & 3 & 2 & 3 \\
\hline 6 & Khairunnisah & 4 & 2 & 1 & 2 & 1 \\
\hline 7 & Ari Pradana & 2 & 1 & 2 & 2 & 2 \\
\hline 8 & $\begin{array}{l}\text { Diana Prata Yanti } \\
\text { Simangungsong }\end{array}$ & 1 & 5 & 3 & 2 & 3 \\
\hline 9 & Tri Rizky Ananda & 3 & 5 & 1 & 1 & 2 \\
\hline 10 & $\begin{array}{l}\text { Wiyuda Pratama } \\
\text { Maharaikan }\end{array}$ & 6 & 5 & 2 & 2 & 2 \\
\hline 11 & Anggy Editya Pratama & 2 & 9 & 3 & 2 & 4 \\
\hline
\end{tabular}

\subsection{Pengelompokan}

Proses pengelompokan data calon penerima beasiswa bidikmisi menggunakan algoritma K-Medoids dengan menggunakan persamaan Euclidean distance.

1. Siapkan sample data yang dikelompokan

2. Tentukan jumlah cluster $(K)$

3. Tentukan nilai centroid / titik pusat secara acak

4. Menghitung jarak dengan persamaan model Euclidean Distance

$$
d_{i j}=\sqrt{\left(x_{1 i}-x_{1 j}\right)^{2}+\left(x_{2 i}-x_{2 j}\right)^{2}+\cdots+\left(x_{k i}-x_{k j}\right)^{2}}
$$

5. Dari hasil perhitungan jarak lakukan cluster / pengelompokan data dengan membandingkan hasil perhitungan jarak dari setiap masing-masing nilai centroid yaitu nilai yg lebih kecil satu cluster dan nilai lebih besar satu cluster

6. Hitunglah total cost yang diperoleh dari perhitungan jarak dengan mengambil nilai terkecil dalam cluster

7. Tentukan nilai centroid / titik pusat terbaru secara acak

8. Hitung jarak dengan persamaan model Euclidean Distance berdasarkan nilai centroid / titik pusat terbaru

9. Dari hasil perhitungan jarak lakukan cluster / pengelompokan data dengan membanding hasil perhitungan jarak dari setiap masing-masing nilai centroid yaitu nilai yg lebih kecil satu cluster dan nilai lebih besar satu cluster

10. Hitunglah total cost yang diperoleh dari perhitungan jarak dengan mengambil nilai terkecil dalam cluster

11. Bandingkan total cost yaitu perhitungan total cost terbaru dengan perhitungan total cost lama. Jika lebih besar total cost terbaru dari pada total cost lama maka proses berhenti, tetapi jika sebaliknya maka proses dilanjutkan kembali dengan penentuan nilai centroid terbaru secara acak[10][11][9].

\section{HASIL DAN PEMBAHASAN}

\subsection{Analisa}

1. Menentukan jumlah cluster (K)

Pada analisa data calon mahasiswa penerima beasiswa bidikmisi, ditentukan cluster (K) yaitu 4(empat) artinya target kelompok data yang dibentuk sebanyak 4(empat) cluster.

2. Menentukan nilai centroid awal / pusat

Selanjutnya ditentukan nilai centroid yang dipilih secara acak dari data calon mahasiswa penerima beasiswa bidikmisi.

Tabel 3. Nilai centroid yang dipilih secara acak

\begin{tabular}{|c|l|c|c|c|c|c|c|}
\hline 1 & Cici Alfiani Pradika Dita & 9 & 7 & 3 & 2 & 4 & Pusat Medoid 1 \\
\hline 2 & Tantri Cepti Buana & 9 & 15 & 3 & 2 & 3 & Pusat Medoid 2 \\
\hline 6 & Khairunnisah & 4 & 2 & 1 & 2 & 1 & Pusat Medoid 3 \\
\hline 11 & Anggy Editya Pratama & 2 & 9 & 3 & 2 & 4 & Pusat Medoid 4 \\
\hline
\end{tabular}

3. Menghitung jarak dengan persamaan Euclidean Distance dan penentuan cluster 
JURNAL MEDIA INFORMATIKA BUDIDARMA

Volume 4, Nomor 3, Juli 2020, Page 797-805

ISSN 2614-5278 (media cetak), ISSN 2548-8368 (media online)

Available Online at https://ejurnal.stmik-budidarma.ac.id/index.php/mib

DOI 10.30865/mib.v4i3.2240

Hasil perhitungan jarak dengan berdasarkan nilai centroid pada Tabel 3 adalah sebagai berikut:

Tabel 4. Rekapitulasi hasil perhitungan jarak

\begin{tabular}{llccccc}
\hline No & Nama & Medoid 1 & Medoid 2 & Medoid 3 & Medoid 4 & Cluster \\
\hline 1 & Cici Alfiani Pradika Dita & $\mathbf{0 , 0 0}$ & 8,06 & 7,94 & 7,28 & 0 \\
2 & Tantri Cepti Buana & 8,06 & $\mathbf{0 , 0 0}$ & 14,21 & 9,27 & 2 \\
3 & Tiara Syahri Hsb & 6,56 & 12,88 & $\mathbf{2 , 0 0}$ & 7,48 & 1 \\
4 & Rasiddin Rambe & $\mathbf{3 , 4 6}$ & 7,42 & 7,28 & 6,86 & 0 \\
5 & Miranda Putri & 5,48 & $\mathbf{3 , 6 1}$ & 10,82 & 5,92 & 2 \\
6 & Khairunnisah & 7,94 & 14,21 & $\mathbf{0 , 0 0}$ & 8,12 & 1 \\
7 & Ari Pradana & 9,49 & 15,72 & $\mathbf{2 , 6 5}$ & 8,31 & 1 \\
8 & Diana Prata Yanti Simangungsong & 8,31 & 12,81 & 5,10 & $\mathbf{4 , 2 4}$ & 3 \\
9 & Tri Rizky Ananda & 7,00 & 11,92 & $\mathbf{3 , 4 6}$ & 5,10 & 1 \\
10 & Wiyuda Pratama Maharaikan & 4,24 & 10,54 & $\mathbf{3 , 8 7}$ & 6,08 & 1 \\
11 & Anggy Editya Pratama & 7,28 & 9,27 & 8,12 & $\mathbf{0 , 0 0}$ & 3 \\
\hline
\end{tabular}

Hasil cluster / pengelompokan didasarkan pada jarak terpendek, jika medoid $1<$ medoid 2 dan medoid $1<$ medoid 3 dan medoid $1<$ medoid 4, maka termasuk dalam cluster 0 , jika medoid $2<$ medoid 1 dan medoid $2<$ medoid 3 dan medoid $2<$ medoid 4 , maka termasuk kedalam cluster 2 , jika medoid $3<$ medoid 1 dan medoid $3<$ medoid 2 dan medoid $3<$ medoid 4, maka termasuk kedalam cluster 1 , dan jika medoid $4<$ medoid 1 dan Medoid $4<$ Medoid 2 dan Medoid 4< Medoid 3 maka termasuk cluster 3.

4. Perhitungan total cost

Hitungan total cost berdasarkan nilai terkecil dari perolehan nilai medoid adalah $0,00+0,00+2,00+3,46+3,61$ $+0,00+2,65+4,24+3,46+3,87+0,00=23,29$, dengan hasil pengelompokan adalah

Cluster $0=\{$ Cici Alfiani Pradika Dita, Rasiddin Rambe $\}$

Cluster $1=\{$ Tiara Syahri Hsb, Khairunnisah, Ari Pradana, Tri Rizky Ananda, Wiyuda Pratama Maharaikan $\}$

Cluster $2=\{$ Tantri Cepti Buana, Miranda Putri $\}$

Cluster $3=\{$ Diana Prata Yanti Simangungsong, Anggy Editya Pratama $\}$

5. Penentuan nilai centroid / titik pusat kedua

Selanjutnya adalah penentuan nilai centroid / titik pusat terbaru secara acak.

Tabel 5. Nilai centroid / titik pusat terbaru secara acak

\begin{tabular}{|l|l|c|c|c|c|c|c|}
\hline 5 & Miranda Putri & 7 & 12 & 3 & 2 & 3 & Pusat Medoid 1 \\
\hline 7 & Ari Pradana & 2 & 1 & 2 & 2 & 2 & Pusat Medoid 2 \\
\hline 10 & $\begin{array}{l}\text { Wiyuda Pratama } \\
\text { Maharaikan }\end{array}$ & 6 & 5 & 2 & 2 & 2 & Pusat Medoid 3 \\
\hline 11 & Anggy Editya Pratama & 2 & 9 & 3 & 2 & 4 & Pusat Medoid 4 \\
\hline
\end{tabular}

6. Perhitungan nilai jarak dengan persamaan Euclidean Distance berdasarkan nilai centroid / titik pusat kedua kedua dan penentuan cluster

Hasil perhitungan jarak dengan berdasarkan nilai centroid/ titik pusat terbaru pada Tabel 5 adalah sebagai berikut:

Tabel 6. Rekapitulasi hasil perhitungan jarak berdasarkan nilai centroid / titik pusat terbaru

\begin{tabular}{llccccc}
\hline No & Nama & $\mathrm{C} 1$ & $\mathrm{C} 2$ & $\mathrm{C} 3$ & $\mathrm{C} 4$ & Cluster \\
\hline 1 & Cici Alfiani Pradika Dita & 5,48 & 9,49 & $\mathbf{4 , 2 4}$ & 7,28 & 1 \\
2 & Tantri Cepti Buana & $\mathbf{3 , 6 1}$ & 15,72 & 10,54 & 9,27 & 0 \\
3 & Tiara Syahri Hsb & 9,54 & 3,87 & $\mathbf{2 , 6 5}$ & 7,48 & 1 \\
4 & Rasiddin Rambe & 4,69 & 9,27 & $\mathbf{3 , 7 4}$ & 6,86 & 1 \\
5 & Miranda Putri & $\mathbf{0 , 0 0}$ & 12,17 & 7,21 & 5,92 & 0 \\
6 & Khairunnisah & 10,82 & $\mathbf{2 , 6 5}$ & 3,87 & 8,12 & 2 \\
7 & Ari Pradana & 12,17 & $\mathbf{0 , 0 0}$ & 5,66 & 8,31 & 2 \\
8 & Diana Prata Yanti Simangungsong & 9,22 & 4,36 & 5,20 & $\mathbf{4 , 2 4}$ & 3 \\
9 & Tri Rizky Ananda & 8,43 & 4,36 & $\mathbf{3 , 3 2}$ & 5,10 & 1 \\
10 & Wiyuda Pratama Maharaikan & 7,21 & 5,66 & $\mathbf{0 , 0 0}$ & 6,08 & 1 \\
11 & Anggy Editya Pratama & 5,92 & 8,31 & 6,08 & $\mathbf{0 , 0 0}$ & 3 \\
\hline
\end{tabular}

Hasil cluster / pengelompokan didasarkan pada jarak terpendek, jika medoid $1<$ medoid 2 dan medoid $1<$ medoid 3 dan medoid $1<$ medoid 4 , maka termasuk dalam cluster 0 , jika medoid $2<$ medoid 1 dan medoid $2<$ medoid 3 dan medoid $2<$ medoid 4, maka termasuk kedalam cluster 2 , jika medoid $3<$ medoid 1 dan medoid $3<$ medoid 2 dan medoid $3<$ medoid 4 , maka termasuk kedalam cluster 1 , dan jika medoid $4<$ medoid 1 dan medoid $4<$ medoid 2 dan medoid $4<$ medoid 3 maka termasuk cluster 3 . 


\section{JURNAL MEDIA INFORMATIKA BUDIDARMA}

Volume 4, Nomor 3, Juli 2020, Page 797-805

ISSN 2614-5278 (media cetak), ISSN 2548-8368 (media online)

Available Online at https://ejurnal.stmik-budidarma.ac.id/index.php/mib DOI 10.30865/mib.v4i3.2240

7. Perhitungan total cost

Hitungan total cost berdasarkan nilai terkecil dari perolehan nilai medoid adalah 4,24 +3,61+2,65 +3,74+0,00+

$2,65+0,00+4,24+3,32+0,00+0,00=24,45$, dengan hasil pengelompokan adalah

Cluster $0=\{$ Tantri Cepti Buana, Miranda Putri $\}$

Cluster $1=\{$ Cici Alfiani Pradika Dita, Tiara Syahri Hsb, Rasiddin Rambe, Tri Rizky Ananda, Wiyuda Pratama Maharaikan\}

Cluster $2=\{$ Khairunnisah, Ari Pradana $\}$

Cluster $3=\{$ Diana Prata Yanti Simangungsong, Anggy Editya Pratama $\}$

8. Perbandingan nilai total cost lama dengan total cost terbaru

Perbandingan nilai total cost lama dengan nilai total cost terbaru yaitu total cost lama =23,29 dan total cost terbaru adalah $=24,45$. Nilai total cost terbaru lebih tinggi dari pada nilai total cost lama sehingga proses pencarian nilai dihentikan. Oleh karena itu, hasil cluster / pengelompokan dari perhitungan nilai centroid terbaru yang digunakan yaitu.

9. Penbentukan Cluster

Cluster 0

Tabel 7. Cluster 0

\begin{tabular}{|c|c|c|c|c|c|c|c|}
\hline No & $\begin{array}{l}\text { Nama } \\
\text { Mahasiswa }\end{array}$ & Calon & $\begin{array}{l}\text { Nilai Ujian } \\
\text { Seleksi }\end{array}$ & Prestasi di Sekolah & $\begin{array}{l}\text { Ekonomi } \\
\text { Keluarga }\end{array}$ & $\begin{array}{l}\text { Status } \\
\text { Kepemilika } \\
\text { n Rumah }\end{array}$ & $\begin{array}{l}\text { Dinding- } \\
\text { Lantai } \\
\text { Rumah }\end{array}$ \\
\hline 2 & $\begin{array}{l}\text { Tantri } \\
\text { Buana }\end{array}$ & Cepti & 20 & $\begin{array}{l}\text { Rata-rata Ranking } \\
15 \text { Kelas }\end{array}$ & $\begin{array}{l}\text { Cukup } \\
\text { Mampu }\end{array}$ & $\begin{array}{l}\text { Milik } \\
\text { Sendiri }\end{array}$ & $\begin{array}{l}\text { Semen } \\
\text { Keramik }\end{array}$ \\
\hline 5 & Miranda Put & & 25 & $\begin{array}{l}\text { Rata-Rata Ranking } \\
12 \text { Kelas }\end{array}$ & $\begin{array}{l}\text { Cukup } \\
\text { Mampu }\end{array}$ & $\begin{array}{l}\text { Milik } \\
\text { Sendiri }\end{array}$ & $\begin{array}{l}\text { Semen } \\
\text { Keramik }\end{array}$ \\
\hline
\end{tabular}

Cluster 1

Tabel 8. Cluster 1

\begin{tabular}{|c|c|c|c|c|c|c|}
\hline No. & $\begin{array}{l}\text { Nama Calon } \\
\text { Mahasiswa }\end{array}$ & $\begin{array}{c}\text { Nilai Ujian } \\
\text { Seleksi }\end{array}$ & Prestasi di Sekolah & $\begin{array}{l}\text { Ekonomi } \\
\text { Keluarga }\end{array}$ & $\begin{array}{c}\text { Status } \\
\text { Kepemilikan } \\
\text { Rumah }\end{array}$ & $\begin{array}{l}\text { Dinding- } \\
\text { Lantai } \\
\text { Rumah }\end{array}$ \\
\hline 1 & $\begin{array}{l}\text { Cici Alfiani } \\
\text { Pradika Dita }\end{array}$ & 20 & $\begin{array}{l}\text { Rata-rata Ranking } 7 \\
\text { Kelas }\end{array}$ & $\begin{array}{l}\text { Cukup } \\
\text { Mampu }\end{array}$ & $\begin{array}{l}\text { Milik } \\
\text { Sendiri }\end{array}$ & $\begin{array}{c}\text { Batu } \\
\text { Keramik }\end{array}$ \\
\hline 3 & Tiara Syahri Hsb & 38 & $\begin{array}{l}\text { Rati-rata Ranking } 3 \\
\text { Kelas }\end{array}$ & $\begin{array}{l}\text { Kurang } \\
\text { Mampu }\end{array}$ & Sewa & Papan Semen \\
\hline 4 & Rasiddin Rambe & 24 & $\begin{array}{l}\text { Rara-rata Ranking } 8 \\
\text { Kelas }\end{array}$ & $\begin{array}{l}\text { Kurang } \\
\text { Mampu }\end{array}$ & $\begin{array}{l}\text { Milik } \\
\text { Sendiri }\end{array}$ & Papan Semen \\
\hline 9 & Tri Rizky Ananda & 41 & $\begin{array}{l}\text { Rata-rata Ranking } 5 \\
\text { Kelas }\end{array}$ & $\begin{array}{l}\text { Tidak } \\
\text { Mampu }\end{array}$ & Sewa & $\begin{array}{l}\text { Semen } \\
\text { Semen }\end{array}$ \\
\hline 10 & $\begin{array}{l}\text { Wiyuda Pratama } \\
\text { Maharaikan }\end{array}$ & 37 & $\begin{array}{l}\text { Rata-rata Ranking } 5 \\
\text { Kelas }\end{array}$ & $\begin{array}{l}\text { Kurang } \\
\text { Mampu }\end{array}$ & $\begin{array}{l}\text { Milik } \\
\text { Sendiri }\end{array}$ & $\begin{array}{l}\text { Semen } \\
\text { Semen }\end{array}$ \\
\hline
\end{tabular}

Cluster 2

Tabel 9. Cluster 2

\begin{tabular}{lllllll}
\hline No. $\begin{array}{l}\text { Nama } \\
\text { Mahasiswa }\end{array}$ & Calon & $\begin{array}{l}\text { Nilai Ujian } \\
\text { Seleksi }\end{array}$ & Prestasi di Sekolah & $\begin{array}{l}\text { Ekonomi } \\
\text { Keluarga }\end{array}$ & $\begin{array}{l}\text { Status } \\
\text { Kepemilikan } \\
\text { Rumah }\end{array}$ & $\begin{array}{l}\text { Dinding- } \\
\text { Lantai } \\
\text { Rumah }\end{array}$ \\
\hline 6 & Khairunnisah & 40 & $\begin{array}{l}\text { Rata-rata Ranking 2 } \\
\text { Kelas }\end{array}$ & $\begin{array}{l}\text { Tidak } \\
\text { Mampu }\end{array}$ & $\begin{array}{l}\text { Milik } \\
\text { Sendiri }\end{array}$ & Papan Semen \\
7 & Ari Pradana & \multirow{2}{*}{43} & $\begin{array}{l}\text { Rata-rata rangking 1 } \\
\text { Kelas }\end{array}$ & Kurang & Milik & $\begin{array}{l}\text { Semen } \\
\text { Mampu }\end{array}$ \\
\hline
\end{tabular}

Cluster 3

Tabel 10. Cluster 3

\begin{tabular}{lllllll}
\hline No. $\begin{array}{llll}\text { Nama } \\
\text { Mahasiswa }\end{array}$ & Calon & $\begin{array}{l}\text { Nilai Ujian } \\
\text { Seleksi }\end{array}$ & Prestasi di Sekolah & $\begin{array}{l}\text { Ekonomi } \\
\text { Keluarga }\end{array}$ & $\begin{array}{l}\text { Status } \\
\text { Kepemilikan } \\
\text { Rumah }\end{array}$ & $\begin{array}{l}\text { Dinding- } \\
\text { Lantai } \\
\text { Rumah }\end{array}$ \\
\hline
\end{tabular}


JURNAL MEDIA INFORMATIKA BUDIDARMA

Volume 4, Nomor 3, Juli 2020, Page 797-805

ISSN 2614-5278 (media cetak), ISSN 2548-8368 (media online)

Available Online at https://ejurnal.stmik-budidarma.ac.id/index.php/mib

DOI 10.30865/mib.v4i3.2240

\begin{tabular}{|c|c|c|c|c|c|c|}
\hline 8 & $\begin{array}{l}\text { Diana Prata Yanti } \\
\text { Simangungsong }\end{array}$ & 47 & $\begin{array}{l}\text { Rata-rata Ranking } 5 \\
\text { Kelas }\end{array}$ & $\begin{array}{l}\text { Cukup } \\
\text { Mampu }\end{array}$ & $\begin{array}{l}\text { Milik } \\
\text { Sendiri }\end{array}$ & $\begin{array}{l}\text { Semen } \\
\text { Keramik }\end{array}$ \\
\hline 11 & $\begin{array}{l}\text { Anggy } \\
\text { Pratama }\end{array}$ & 43 & $\begin{array}{l}\text { Rata-rata Rangking } \\
9 \text { Kelas }\end{array}$ & $\begin{array}{l}\text { Cukup } \\
\text { Mampu }\end{array}$ & $\begin{array}{l}\text { Milik } \\
\text { Sendiri }\end{array}$ & $\begin{array}{l}\text { Batu } \\
\text { Keramik }\end{array}$ \\
\hline
\end{tabular}

Dari cluster / pengelompokan data calon penerima beasiswa bidikmisi di Universitas Budi Darma dengan algoritma K-Medoids, dengan mempertimbangkan berbagai kriteria yaitu nilai ujian seleksi, prestasi di sekolah, ekonomi keluarga, status kepemilikan rumah dan dinding lantai rumah, maka yang lebih layak mendapatkan beasiswa bidikmisi adalah cluster 2 .

\subsection{Pengujian}

Tampilan hasil import data calon penerima beasiswa bidikmisi di Universitas Budi Darma, dimana data tersebut sudah rubah dalam bentuk angka diaplikasi rapidminer[12][13].

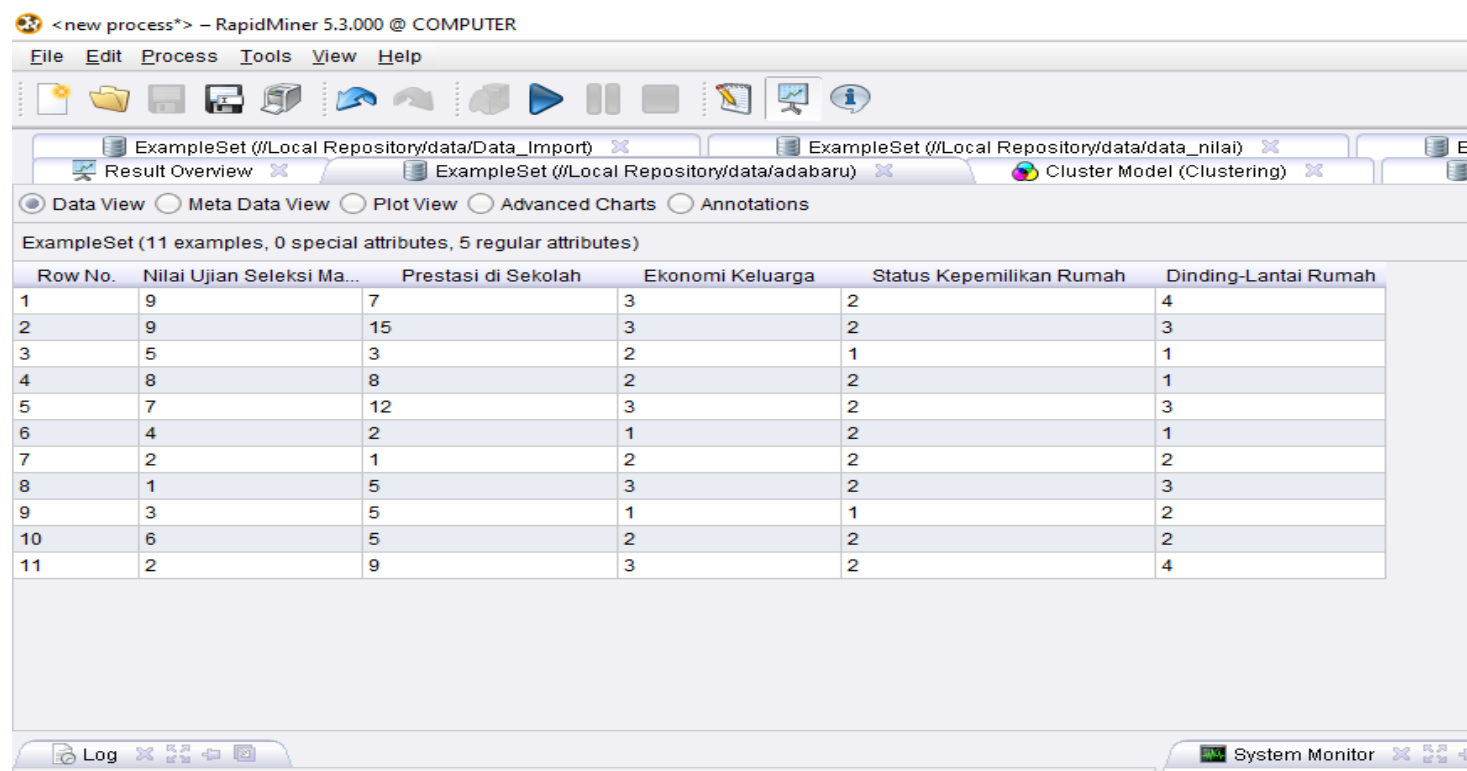

Gambar 2. Import data calon penerima beasiswa bidikmisi

Proses menghubungkan data calon mahasiswa penerima beasiswa bidikmisi dengan K-Medoids.

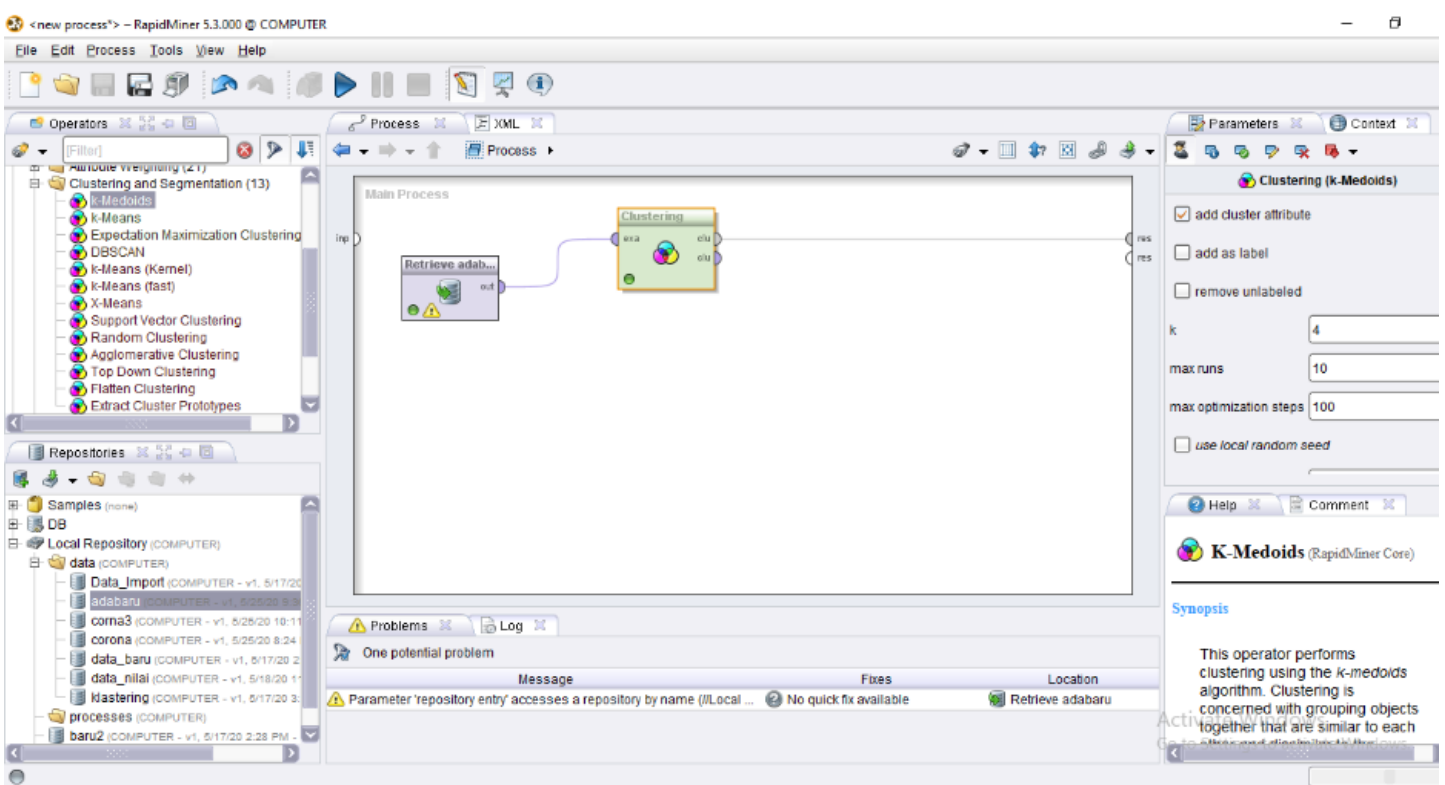

Gambar 3. Data calon penerima beasiswa bidikmisi dengan K-Medoids 
JURNAL MEDIA INFORMATIKA BUDIDARMA

Volume 4, Nomor 3, Juli 2020, Page 797-805

ISSN 2614-5278 (media cetak), ISSN 2548-8368 (media online)

Available Online at https://ejurnal.stmik-budidarma.ac.id/index.php/mib

DOI 10.30865/mib.v4i3.2240

Hasil pengelompokan data dengan K-Medoids dalam bentuk cluster model.

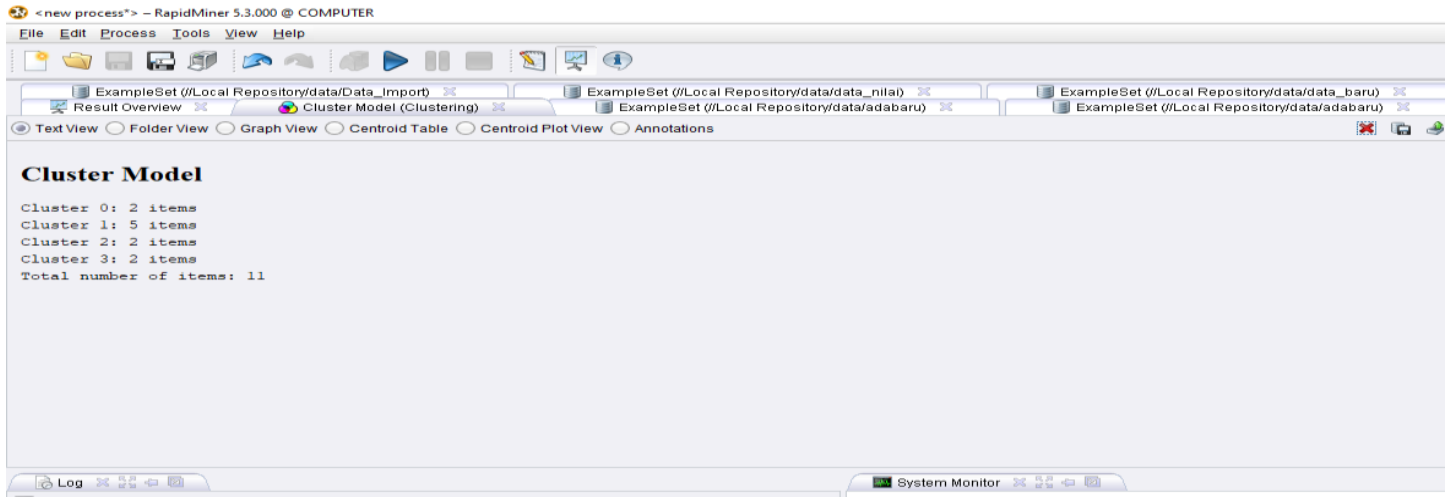

Gambar 4. Pengelompokan data dengan K-Medoids dalam bentuk cluster model

Hasil cluster / pengelompokan data dengan K-Medoids dalam bentuk root cluster.

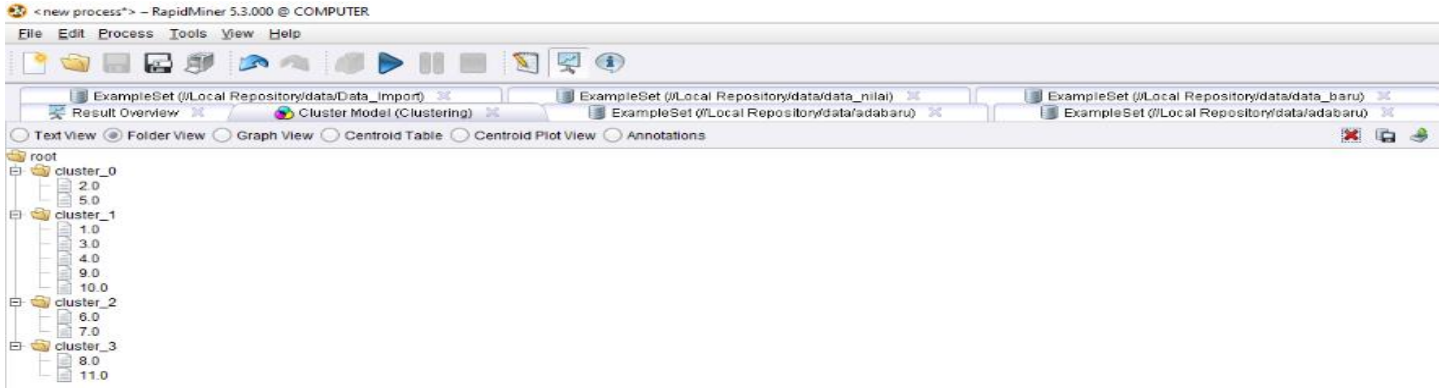

Gambar 5. Cluster dengan K-Medoids dalam bentuk root cluster

Hasil pengujian data calon mahasiswa penerima beasiswa bidikmisi dengan aplikasi rapidminer dengan menggunakan K-Medoids mempunyai hasil yang sama dengan perhitungan manual dengan algoritma K-Medoids dimana cluster 0 terdiri atas data nomor 2 dan 3. Cluster 1 terdiri atas data nomor 1, 3, 4, 9, 10. Cluster 2 terdiri atas data nomor 6 dan 7. Cluster 3 terdiri atas data nomor 8 dan 11.

\section{KESIMPULAN}

Berdasarkan uraian diatas, dapat ditarik kesimpulan bahwa algoritma K-Medoids dapat diterapkan dalam menentukan calon mahasiswa yang layak mendapatkan beasiswa bidikmisi di Universitas Budi Darma. Proses cluster / pengelompokan data calon mahasiswa penerima bidikmisi dengan algoritma K-Medoids secara manual mempunyai hasil cluster / pengelompokan yang sama dengan pengujian data yang sama dengan aplikasi rapidminer. Data calon mahsiswa penerima beasiswa bidikmisi dapat dibentuk kedalam 4(empat) cluster, cluster 0 terdiri atas 2 anggota, cluster 1 terdiri atas 5 anggota, cluster 2 terdiri atas 2 anggota, dan cluster 3 terdiri atas 2 anggota.

\section{REFERENCES}

[1] Ditjen Belmawa Kemenristekdikti, Penduan Pendaftaran Beasiswa Bidikmisi 2019. Jakarta: Ristekdikti, 2019.

[2] E. Buulolo, "Implementasi Algoritma Apriori Pada Sistem Persediaan Obat ( Studi Kasus : Apotik Rumah Sakit Estomihi Medan )," Pelita Inform. Budi Darma, vol. 4, no. Agustus 2013, pp. 71-83, 2013.

[3] A. Widayanti, "Analisis Kluster untuk Mengelompokkan Performansi Mahasiswa Fakultas Ilmu Terapan Ditinjau dari Bidang Akademik dan Non Akademik,” J. Teknol. Inf., vol. 1, no. 6, pp. 229-231, 2013.

[4] A. Syahrin, "Implementasi algoritma k-means untuk klasterisasi mahasiswa berdasarkan prediksi waktu kelulusan skripsi," UPN "Veteran" Jatim, vol. 1-23, 2013.

[5] D. F. Pramesti, Lahan, M. Tanzil Furqon, and C. Dewi, "Implementasi Metode K-Medoids Clustering Untuk Pengelompokan Data,”J. Pengemb. Teknol. Inf. dan Ilmu Komput., vol. 1, no. 9, pp. 723-732, 2017.

[6] W. A. Triyanto, "ALGORITMA K-MEDOIDS UNTUK PENENTUAN STRATEGI PEMASARAN PRODUK," Simetris J. Tek. Mesin, Elektro dan Ilmu Komput., 2015.

[7] J. O. Ong, "Implementasi Algotritma K-means clustering untuk menentukan strategi marketing president university," J. Ilm. Tek. Ind., vol. vol.12, no, no. juni, pp. 10-20, 2013.

[8] A. Bhat, "K-Medoids Clustering Using Partitioning Around Medoids for Performing Face Recognition," Int. J. Soft 
JURNAL MEDIA INFORMATIKA BUDIDARMA

Volume 4, Nomor 3, Juli 2020, Page 797-805

ISSN 2614-5278 (media cetak), ISSN 2548-8368 (media online)

Available Online at https://ejurnal.stmik-budidarma.ac.id/index.php/mib

DOI 10.30865/mib.v4i3.2240

Comput. Math. Control, 2014.

[9] P. Arora, Deepali, and S. Varshney, "Analysis of K-Means and K-Medoids Algorithm for Big Data," in Physics Procedia, 2016.

[10] E. Buulolo, Data Mining Untuk Perguruan Tinggi. Yogyakarta: deepublish, 2020.

[11] I. Kamila et al., "Perbandingan Algoritma K-Means dan K-Medoids untuk Pengelompokan Data Transaksi Bongkar Muat di Provinsi Riau," vol. 5, no. 1, pp. 119-125, 2019.

[12] Aprilla Dennis, "Belajar Data Mining dengan RapidMiner," Innov. Knowl. Manag. Bus. Glob. Theory Pract. Vols 12 , 2013.

[13] V. Kotu and B. Deshpande, Predictive Analytics and Data Mining: Concepts and Practice with RapidMiner. 2014. 